Jorgen Holmgaard

\title{
En kritisk teoretikers intellektuelle testamente
}

\section{Omkring Leo Lowenthal's Litteratursociologi-et tilbageblik}

Leo Lowenthal har en særlig profil i Frankfurter-skolens galleri af personligheder. Alene ved ikke at markere sig så idiosynkratisk som en Adorno, en Marcuse eller en Walter Benjamin har gjort det, skiller han sig ud i selskabet. En anden side af den samme forskellighed er stilistisk-retorisk. Hvor Adorno balancerer mellem argument og metafor, Marcuse udfolder sig i bred epik og Benjamin bunker sine pointilistisk-aforistiske notater, er Lowenthal demonstrerende og ræsonnerende, pædagogisk og overtalende mere end berusende, hvilket de andre godt kan være, hver på sin vis.

Det har måske at gøre med en tredie side af monstret: Lowenthal er den, der kommer tættest på en gængs litteraturforsker; de andre bevæger sig i de mere uafgrænsede områder, der strækker sig mellem eller ind over filosofi, æstetik og forskellige historiske discipliner. For Lowenthal er det litterære et analyseobjekt, der indsamles og gennemarbejdes. For de andre er det en eksempelsamling - blandt andre - , hvorfra der udtages velegnede elementer til fremføring i dialektisk belysning. Herover hviler altid et associationsrigt "promesse de bonheur", som den informative Lowenthal ikke frembringer. Omkring disse forskelle ligger Lowenthals force såvel som hans begrænsning.

Forcen kommer frem ved en lejlighed som dette tilbageblik. Heri markerer han åbent nogle centrale positioner i Frankfurterskolen, som hos andre må vristes frem ved analyse for at træde i karakter. Vigtigst af disse forekommer måske marginalitetstemaet. Få, der er blevet tiltrukket af den kritiske tradition, som Lowenthal er den ældste nulevende repræsentant for, har i tidens løb gjort det - eller sig klart, i hvor høj grad dens indhold var en marginal- eller minoritetsfilosofi. En elitefilosofi, set fra et andet synspunkt. Det var i allerhøjeste grad virkeligheden på stamfader Marx' tid, uanset hvor meget de fordrevne tyske intellektuelles »Internationale« kunne vokse i de 
samtidige borgerlige avisers mareredne forestillingsverden. Da arbejderbevægelsen blev en masserealitet fra 1870'erne, forblev teoretikerne i exil og isolation. Deres ret til at representere en bredere social realitet har i bedste fald været honorær, som Marx' og Engels' position i forhold til det tyske socialdemokrati i deres sidste år.

Den klassiske, kritiske filosofi over for dette centrale problem har været teorien om, at marginaliteten var midlertidig. I hele den eftermarxske traditions mest betydningsfulde enkeltværk - Geschichte und Klassenbewusstsein - udarbejdede Lukacs den systematisk: den revolutionære Teori må repræsentere indsigten i det proletariske flertals objektive interesse, indtil det selv når frem til den. Endnu i Horkheimers og Adornos skrifter fra 30'rne fortsætter referencen til proletariatet, omend den bliver udtrykt i stadig mere vage og forsigtige ord. Men i 40'rne forsvinder proletariatet fra Frankfurterskolens vokabularium og erstattes af referencer til »totaliteten « eller synonyme omskrivninger af den store sammenhæng, som marginalitetens teoretikere stadig må hæude, de repræsenterer. Samtidig slår håbet om marginalitetens og helhedens, teoriens og virkelighedens forening over $\mathbf{i}$ undergangsprofetiske toner, hvis rette modtager er svær at lokalisere. Først i Marcuses 60'erskrifter bliver Teoriens sandhed igen befolket med socialt eksisterende fænomener, ikke mere proletariatet, men en konstellation af nye revolutionære kræfter, bl.a. de marginaliserede befolkningsmasser i u-landene.

Gennem alle håb og skuffelser har den kritiske teori imidlertid været i stand til at opretholde en usvækket overbevisning om sin egen sandhed og dennes gyldighed for samfundshelheden. Marginaliseret og skuffet $\mathrm{i}$ alle forudsigelser har Teorien været, men den mistede aldrig selvtilliden. Heri ligger en højbenet, men urokkelig åndsaristokratisme, som allerede var en af Marx' psykologiske overlevelsesmekanismer, ikke mindst når de teoriudledte prognoser blev dementeret af virkelighedens udvikling og ingen iøvrigt kerede sig derom.

Denne ellers næsten uundgåelige erhvervssygdom for kritiske teoretikere har imidlertid kun udviklet sig i ringe grad hos Lowenthal. Det spiller en rolle, hvilket tidspunkt han skriver på, og hvilken alder han har. Men han har derudover en behagelig beskedenhed, som gør, at han i modsætning til sine kolleger kan tematisere marginaliteten direkte uden at skulle dække den ind bag facader og kompensere den med en gigantisk selvfølelse. Til gengæld bliver det så også meget klart, hvad der alligevel skal til for at opretholde positionen. Dels må han forherlige »kollektivet af udstødte« (»the collective of outcasts «). Dels må han for ikke at synke ned i værdirelativisme - opgive teoriens absolutte sandhedskrav - operere med et støttepunkt hinsi- 
des det givne samfund: naturen. Teorien om samfundsstrukturen som en fundamental fordrejning af en oprindelig, 'første' natur i og uden for mennesket peger direkte tilbage til Adorno og Horkheimers Oplysningens Dialektik. Men tankegangen går gennem hele den kritiske og marxistiske teori tilbage til den tyske romantiske filosofi og den romantiske intellektuelles fortolkning af sit konfliktforhold til samfundet.

Marginalitetsfænomenet er tæt forbundet med en kunst- og kunstnerfilosofi. Lowenthal ligger på linie med Adorno, når han tillægger den marginaliserede og isolerede kunstners »fordrejede« syn på verden sandhedsværdi: netop i al sin fordrejethed er det sandt, fordi verden er fordrejet. Argumentet hviler på en påstand om, at den sande indsigt $\mathrm{i}$ virkeligheden er mulig, altså en erkendelsesabsolutisme. I al sin isolation kan kunsten derfor representere den sande kollektivitet, mens virkelighedens empiriske kollektivitet kun er et manipuleret, konformt og »falsk « menneskeligt fællesskab. Som man kan se endnu en variation $i$ bearbejdningen af marginaliteten. Den kan kritiseres fra mange vinkler. Men tilbagetrækningen til den introverte kunstdyrkelse er naturlig for den humanistiske intellektuelle og konsistent nok i forhold til præmisserne, givet samfundet er som det er - en stadig anfægtelse af teorien. Den »ukunstneriske«, politiske logik over for konflikten mellem marginaliteten og den sociale virkelighed, der ikke vil hvad teorien vil, frrer i sin konsekvens til den del af spektret, der afgrænses af kadrepartiet og terrorismen.

Af kunstfilosofien følger et absolut vurderingssæt. Fra Lowenthals position er der ingen problemer $\mathrm{i}$ at skelne mellem kunst og ikkekunstnerisk massekultur, og mellem god og dårlig kunst. Den slags synspunkter er absolut ikke »in« - i hvert fald i Danmark - og vanskelige at forsvare inden for den horisontale, demokratiske erfaringshorisont, de fleste befinder sig i nu. Men den kritiske teoretiker har en anden baggrund. Han er oprindeligt den elitære intellektuelle, der har valgt »das Reich der geistigen Werte" frem for de dominerende sociale realiteters lavere echelon. Selv Marx var jo oprindeligt litterat og filosof, og årtier senere blev han ved med at omtale sine samfundsstudier som »det økonomiske lort«.

I de politiserede teorier fra Marx over Lukacs til Frankfurterskolen konstrueres i tanken planen om en forening af de to riger under de intellektuelles supremati. Det sidste siges dog ikke direkte. Men planen bliver sjældent til virkelighed. Vist tilbage fra den sociale realitet og genankommet til kunstens verden, bliver det derfor tit en naturlig reaktion for den kritiske intellektuelle $\mathrm{i}$ hvert fald at ville være herre over værdierne på denne plads. 
Men hvorfra i det hele taget projektet om at gribe ind? Hvorfor er de intellektuelle ikke blevet i deres elfenbenstaarn? Det moralske ansvar, er svaret. Et ansvar, som hos den intellektuelle er ekstra stort, alene $\mathrm{i}$ og med, at han besidder det privilegium at leve et liv som intellektuel. Lowenthal går her direkte til roden af en sammenhæng, som størstedelen af den marxistisk-kritiske tradition har gjort alt for at fortrænge og rationalisere. I alle de kritiske projekter har der været blandede psykologiske drivkræfter involveret. Men mærkelig nok har den ingrediens, som har udløst de stærkeste skamfølelser og de mest energiske bortforklaringer, været samvittigheden, medlidenheden med den sociale strukturs ofre. Videnskabeligheden, den objektive lovmæssighed har været den gentagne gestus, hvormed den moralske bevægetheds varme er blevet gjort til kold kritisk instrumentalisme, som teoretikeren har kunnet præsentere $\mathrm{i}$ den sociale yderverden uden at skamme sig. Den verbale brutalitet over for "sentimentale» samfundsreformatorer, som allerede Marx udviklede til mesterskab, viser bedre end meget andet, hvad der er på færde i dette fortrængte, dybt paradoksale kompleks. Og så kommer Lowenthal og vedgår uden falbelader, hvordan det hænger sammen. Der ligger heri en psykologisk styrke, som man skal lede længe efter i den tradition, han er udgået fra. Det er med den samme styrke han i slutlinierne kan placere den intellektuelles dialog med kunsten i sin psykiske økonomi: den er nok det bedste middel til at leve i den marginalitet, der $\mathrm{i}$ I.owenthals perspektiv er såvel forudsætningen for social indsigt og social samvittighed som disses uundgåelige konsekvens.

Kortheden til trods afmærker Lowenthal i denne artikel alle væsentlige vinkler i den indre og ydre problematik, som siden den franskc revolution har stillet sig for den europæiske intellektuelle: at være indsocialiseret med humanistiske - og afledt herfra: politiske - idealer, som den samfundsmassige virkelighed slet ikke har kunnet leve op til. I den centraleuropæiske sammenhæng, som Lowenthal kommer fra, har denne spænding været ekstrem, givet det barbariske politiske og det feudalt stive sociale system, der historisk har hersket $i$ denne region. Deraf extremiteten i de svar, som den tyske intellektuelle tradition har produceret.

Spændingen mellem det intellektuelle subjekt og den sociale omverden er $\mathrm{i}$ de fleste vestlige lande blevet mindre antagonistisk end før, og andre af problematikkens instanser har forrykket sig takket være en tendens mod kulturel demokratisering og en voksende social mobilitet. Alligevel er Lowenthals problemer og løsninger ikke kun historiske. Den melankolske og intellektuelle yuppie, der med postmodernismen afløste den kritiske traditions tragiske ekstremist eller 
introverte, er næppe verdenshistoriens ultimative bud på en intellektuel position. Eller som den sensitive amerikanske kulturjournalistik allerede har registreret: yuppien er nu passé og den moralske sociale samvittighed er atter på vej op. 